


$$
\begin{array}{r}
\text { A Publication of the } \\
\text { Institute of Industrial Relations } \\
\text { University of California }
\end{array}
$$




\section{TRADE UNION DEMOCRACY IN WESTERN EUROPE}

WALTER GALENSON

University of California Press

Berkeley and Los Angeles, 1962 
Unioersity of Callformia Press Berkeley and Los Angeles, Callfornta Cambridge Untveroty Press, London, England

(C) 1961 by The Regents of the Untoerstiy of California

Second Printing, 1962

Library of Congrest Catalog Card Number: 61-6779

Manufactured in the Untted States of America 


\section{FORE WORO}

Walter Galenson's study of Trade Union Democracy in Western Europe was conducted under the auspices of the Trade Union Study of the Center for the Study of Democratic Institutions. Supported by a generous grant from the Fund for the Republic, the Trade Union Study has been planned and directed by a committee under the chairmanship of Clark Kerr, President of the University of California. The other members of the committee are Benjamin Aaron, Walter Galenson, Paul Jacobs, Seymour M. Lipset, Philip Selznick, and W. Willard Wirtz. Four of the committee members (Kerr, Galenson, Lipset, and Selznick) are also members of the research staff of the Institute of Industrial Relations on the Berkeley campus of the University, while Benjamin Aaron is Director of the Institute of Industrial Relations on the Los Angeles campus. Thus the Institute has been closely associated with the Trade Union Study and is pleased to coöperate with the committee in sponsoring the publication of Professor Galenson's monograph. 


\section{PREFACE}

In this study, Walter Galenson has fulfilled a double purpose. On the one hand, he has written an excellent summary description of the structure of the European labor movement. That, in itself, is an accomplishment. On the other hand, he has made a very real contribution to the discussion of democracy and trade unionism in America. By helping us to see Europe, he helps us to see ourselves.

For example, it has been axiomatic among trade unionists in the United States that "dual unionism" is a serious evil. Indeed, there was an effort which lasted almost two decades which finally brought the AFL and the CIO together and produced the "No Raiding" agreement. But now, another question develops: has the worker lost some freedom of choice in that he no longer has the option to move to another International or another Federation? In the years since the merger of the AFL and the CIO, this issue has become more and more compelling. 


\section{Preface}

Walter Galenson's study will not solve the American problem. But, by describing the variety of practices and attitudes in Europe, it makes a significant contribution to the discussion. In Belgium, Holland, and Austria there is dual unionism, and the labor movements of those countries accept this as a healthy, positive situation. In France and Italy, on the other hand, unions function in a different social context. This context reinforces the tendencies of weakness and factional political fragmentation in the labor movement.

Obviously, the fact that dual unionism works well in one country does not mean that it can be transplanted to the United States. As Galenson makes clear, the structure of unionism grows out of the economy, the social and political history, of a nation. In the United States, the Wagner Act made a momentous option for the concept of exclusive jurisdiction. This decision has now become integrated into our trade union life. It, along with a range of economic, historic, and social factors, has given real power to the traditional American rejection of dual unionism.

And yet understanding the European attitudes and practices does help to focus the question. It opens up a whole range of reference for the discussion which is taking place in America. Similarly with other problems. In Sweden and Britain, for instance, there is no real internal competition within the labor movement, yet this has not led to antidemocratic practices on a wide basis.

Or there is the question of the nonparticipation of the member in the affairs of his union. As this study makes plain, this is a problem in all the advanced nations. Yet the reason for it varies from country to country. In France and Italy, it is related to the weakness (really the absence) of strong locals; in Britain, it represents a change, part of the movement toward national bargaining; in Sweden, it may well be a function of the very success of the trade union movement. These facts do not carry with them some automatic conclusions of the problem of nonparticipation in America. Rather, they point out lines of investigation; they reveal possibilities which might not be so obvious to us.

Then, there are the white collar unions of Sweden. They are successful, organizationally independent of the blue collar unions, politically neutral, and they emphasize shop bargaining. Clearly, this is a phenomenon of importance for American unionists who are more and more faced with the possibility of organizing white 
collar and service workers. Walter Galenson's description is, of course, a summary one, yet even in broad outline the fact of white collar unionism in Sweden is tremendously relevant to the American labor movement today.

The examples could be multiplied many times over, but the main point should be obvious.

We of the Trade Union Study of the Center for the Study of Democratic Institutions have concentrated upon the problem of freedom in American unions. This study by Walter Galenson is a valuable addition to the literature of scholarship, an extremely useful survey of European trade union structures. But at every point it is also, at least by implication, a contribution to the discussion of the labor movement in America. We cannot become "visitors from Mars" so as to see our institutions without any assumptions or bias. We can, however, become visitors to other nations, to other labor movements, and in the doing we can gain a new angle of vision upon the issue of democracy in our industrialized society. This Walter Galenson helps us to do, and we are in his debt. 


\section{ACKNOWLEDGMENTS}

This study is based largely upon interviews conducted in Europe during the spring and summer of 1959. It does not pretend to be encyclopedic. On the contrary, it covers only those aspects of the subject which are of greatest current interest either in Europe or in the United States. A thorough monographic treatment would require years-not months-of investigation and analysis.

A great many persons gave generously of their time and advice, too numerous to mention here. However, I must at least acknowledge the assistance of those who went to the trouble of scheduling interviews for me; without their help it would have been impossible to utilize the limited time at my disposal at all effectively. They are: Hugh Clegg, Nuffield College, Oxford University; Allan Flanders, Institute of Statistics, Oxford University; Henning Friis, Director, the Danish National Institute of Social Research; Dr. Gino Guigni, Institute of Industrial Reconstruction, Rome; Professor Charles A. Gulick, University of California, Berkeley; 
Daniel Horowitz, Labor Attaché, United States Embassy, Paris; Haakon Lie, General Secretary, Norwegian Labor party; Professor Val R. Lorwin, University of Oregon; Dr. Gustavo Malan, Director, European Institute for Economic Studies, Turin; Professor Jan Pen, University of Groningen; Gösta Rehn, Economist, Swedish Federation of Labor; Dr. Philip Rieger, Vienna Chamber of Labor; and Professor A. J. Rüter, Director, International Institute of Social History, Amsterdam.

It is one of the purposes of the Fund for the Republic, which sponsored this study, to stimulate discussion of public issues. I have tried to do my part by eschewing academic detachment and expressing my own opinion whenever it seemed appropriate. But it would be the height of ingratitude to incriminate those who were kind enough to help me, so that it is necessary to append the customary avowal of sole responsibility for all the views that appear in the following pages.

W. G. 